\title{
Chapter 5 Resistant personality and burnout in judo athletes from national teams
}

Capítulo 5 Personalidad resistente y burnout en deportistas de judo seleccionados nacionales

PONCE-CARBAJAL, Nancy†*', LÓPEZ-WALLE, Jeanette M.' and MÉNDEZ-SÁNCHEZ, María del Pilar"

'Universidad Autónoma de Nuevo León, School of Sports Organization, Mexico.

"Universidad Nacional Autónoma de México, Facultad de Estudios Superiores Zaragoza, Mexico.

ID $1^{\text {st }}$ Author: Nancy, Ponce-Carbajal / ORC ID: 0000-0002-8370-9378, CVU CONACYT ID: 556867

ID $1^{\text {st }}$ Co-author: Jeanette M., López-Walle / ORC ID: 0000-0003-1552-7756, CVU CONACYT ID: 121353

ID $2^{\text {nd }}$ Co-author: María del Pilar, Méndez-Sánchez / ORC ID: 0000-0003-0066-5582, CVU CONACYT ID: 263502

DOI: $10.35429 / \mathrm{H} .2021 .10 .66 .72$

N. Ponce, J. López and M. Méndez

* NANCY.PONCECRB@uanl.edu.mx

A. Marroquín, J. Olivares, D. Ventura, L. Cruz. (Coord.) CIERMMI Women in Science TX Humanities and Behavioral Sciences. Handbooks-OECORFAN-México, Querétaro, 2021. 


\begin{abstract}
The objective of this book chapter is to identify the correlations between Hardy Personality (HP) and Burnout (MT), in high performance athletes. The participants were 162 Athletes from their national teams from 21 countries in Judo Sport, who participated in Mundial de Veteranos de Judo and Grand Prix in 2019 in Cancun Quintana Roo, Mexico, the age ranged from 18 to 70 years with an Average of 32.56 and a Standard Deviation of 11.48. The athletes answered two instruments, one that measures the RP that evaluates their resistance to stress, and the other that measures the Burnout. The methodology used is cross-sectional, associative empirical, and simple correlation. Descriptive analyzes, reliability, validity, and Spearman's correlations were performed, with SPSS software. The results found negative and significant relationships in the resistant trifactorial and unifactorial personality. Judokas are perceived as resistant to stress and capable of overcoming any obstacle, there is no depletion or devaluation of their sports practice.
\end{abstract}

\title{
Hardy personality, Control, Resistance personality, Commitment, Athletes
}

\section{Resumen}

El objetivo de este capítulo de libro es identificar las correlaciones entre la Personalidad Hardy (HP) y el Burnout (MT), en deportistas de alto rendimiento. Los participantes fueron 162 atletas de sus equipos nacionales de 21 países en el deporte de Judo, que participaron en el Mundial de Veteranos de Judo y Grand Prix en 2019 en Cancún Quintana Roo, México, la edad osciló entre 18 y 70 años con un Promedio de 32,56 y una Desviación Estándar de 11,48. Los deportistas contestaron dos instrumentos, uno que mide la RP que evalúa su resistencia al estrés y otro que mide el Burnout. La metodología utilizada es transversal, empírica asociativa y de correlación simple. Se realizaron análisis descriptivos, de fiabilidad, validez y correlaciones de Spearman, con el software SPSS. Los resultados encontraron relaciones negativas y significativas en la personalidad resistente trifactorial y unifactorial. Los judokas se perciben como resistentes al estrés y capaces de superar cualquier obstáculo, no hay agotamiento ni desvalorización de su práctica deportiva.

\section{Personalidad resistente, Control, Personalidad resistente, Compromiso, Deportistas}

\subsection{Introduction}

Sport has been a tool used for the protection of health for decades as shown by Kobasa (1979) and at present it is an activity that is sustained and that has been followed by the benefits it offers to society in general, has become a core activity to support the improvement of the health of the masses, that is why international sporting events such as the Olympic Games impact young people who, seeing the example of elite athletes, begin in training and development of systematic practice of the sport of their choice and this is documented by Bauman, Bellew, and Craig (2014), where they describe how there is a positive impact on society. And not only do they encourage them to practice sports, it also increases their motivation and self-confidence (De la Cruz, 2020).

Hence, the importance of this type of study, since this specific sample is athletes of international stature with many years of practice, which allows us to show the perception they have of themselves in the face of sport and the benefits that they have represented. in the course of his sports career, and allows us more accurately to identify his resistance to stress and the limits in turn caused by Burnout. The added value is that with the results and our conclusions, it becomes known what has kept them training for so many years, such as their ability to control, commitment and challenge their sports practice and that transform it into information that serves the new generations providing conclusions that allow us to identify the needs that helped these sports heroes, and this reduces the time of trial and error in the new generations and at the same time prevents athletes in training from reaching the state of burnout that is an extreme of emotional fatigue that We do not want it to happen, so that would avoid defections to the objectives that athletes set in their sports careers and with this, they can formulate a multi-collaborative strategy between parents, coach, authorities and the athlete himself so that he can achieve the sports success. As a conclusion to this work, offer a strategy that helps to keep athletes focused on their goals and resistant to possible setbacks that are part of training and not necessarily fall into abandonment of the activity. 
It is worth mentioning that high performance athletes participate in a participation in two different contexts such as sports and social, which represents a greater number of activities, as well as the sports part with all that it implies in the social context. It is also necessary to participate and respond in the family and school environment, which represents a certain increase in stress for athletes (Bronfenbrenner 1987; Avilés et al., 2018).

The instruments with their characteristics that were used are two, the first is the resistant personality, a concept referred to the resistance to stress of the participants, and the capacity they demonstrate in surprising, difficult situations or that represent a great commitment, where the Individuals transform all these difficulties into processes of development and growth, however not all subjects have this capacity and even some have reduced their emotional and even physical health. This concept is composed of three variables, which are: Commitment $(\mathrm{CO})$, Control $(\mathrm{C})$ and Challenge $(\mathrm{CH})$, each variable of 6 items and composed of 18 questions that measures the resistant personality as a single set, or in a trifactorial way. (Ponce, 2017). The second is Burnout It is a syndrome that appears when the subjects do not achieve expected results, regardless of their efforts and dedication in their activity, gradually causing mental and physical fatigue that is manifested by a lack of energy, interest and leading to a lack of motivation. This concept is composed of three variables identified as Physical Emotional Exhaustion (PEE), Reduced Sense of Achievement (RSA) and Devaluation of Sports Practice (DSP), this questionnaire is made up of 15 questions, each variable made up of 5 items (Balaguer, Castillo, Duda, Quested, and Morales, 2011). Some studies have been carried out in diverse samples such as psychologists and nutritionists (Gonzáles, 2021) and also in Mexican athletes (Salazar-González, D., Cantú-Berrueto, López-Walle, Berengüí, 2020) and another study has been specifically carried out in footballers by Figueroa and Patiño 2021).

The problem statement is that the sports population has the challenge of controlling various emotional situations to avoid abandoning training due to lack of control, commitment or that the challenges of sports practice are leading to burnout syndrome such as burnout. Since if the coach is too demanding or the parents put too much pressure on the athlete by not achieving the expected success, they may feel unmotivated to carry out the training sessions and make it more attractive not to continue practicing anymore and to abandon their sport.

The working hypothesis is the following: Which PR factors correlate with the Burnout variables?

The chapter of the book is organized as follows, in the first part the introduction is presented, which describes in a general way the beneficial effects of sport on society in general and the theoretical framework on which the study variables are discussed as They are the resistant personality and burnout, in turn the variables that make up said questionnaires are presented and the general concepts of said instruments are mentioned, later the issue of the importance of sport and the benefits it provides is addressed. later the statement of the problem and the central hypothesis of this research is carried out. In the second part, the methodological framework is presented where the topics of the research design, the sample, the evaluation instruments used, the components and the number of items of each of them are discussed, after this the procedure that It was carried out for the sampling and the statistical analyzes described as descriptive analyzes, frequency analysis, the mean, the standard deviation, reliability and correlations are reflected. The third part presents the results where the values found in said statistical analyzes are described. In the fourth part the thanks to the institutions that have provided support are reflected and in the fifth part the conclusions are arranged with concise strategies of what is stated in this research and as the last section the references where all those consulted sources have been arranged.

\subsection{Description of the Method}

The design of this research is empirical associative, simple correlation and cross-sectional (Ato, LópezGarcia, \& Benavente, 2013), the sample is composed of 169 national selected Judo athletes from 21 countries, participants in the Veterans World Cup and the International Grand Prix, held in Cancun Quintana Roo in 2018, the age of the participants ranges between 18 and 70 years $(\mathrm{M}=32.56, \mathrm{SD}=$ 11.48), of which 92 are men (59\%) and 64 women and 13 subjects who preferred not to put their gender, representing $7.7 \%$. 
The first of the instruments used to measure resistant personality was the Resistant Personality questionnaire in Athletes from Central America and the Caribbean (RPAAC; Ponce et al., 2015) this questionnaire consists of 18 items: 6 commitment, 6 items that measure the control dimension, and 6 challenge. The Likert-type scale is 4 points where 0 totally disagree to 3 totally agree. The reliability of Cronbach's alpha of the RPAAC variables ranges between .71 and .72 (Ponce, 2017).

The second of the instruments used to measure burnout syndrome is the Sports Burnout Questionnaire (Athlete Burnout Questionnaire; ABQ; Raedeke \& Smith, 2001). The questionnaire is composed of 15 items and three variables that are: Reduced Sense of Achievement (RSA), Physical and Emotional Exhaustion (PEE) and Devaluation of Sports Practice (DSP), each of 5 items. The items are evaluated in such a way that, the higher number is a higher degree of burnout, with two exceptions in items 1 and 14 of the RSA subscale, which are presented inversely, that is, the lower the numerical response, the degree of burnout is higher. The response scale is Likert type and ranges from (1) Almost never to (5) Almost always. The reliability of Cronbach's alpha of the Burnout variables ranged between .75 and .83 (Salazar-González, Cantú-Berrueto, López-Walle, Berengüí, 2020).

The Procedure began by requesting permission to the Mexican Judo Federation, requesting support to carry out the investigation, subsequently contact was made with the organizing committee to request the accreditation of said event with the consent of the Mexican Judo Federation this credential allowed the intervention and approach to the various training and competition venues with coaches from different countries, where the objectives of the investigation were explained to them through a brief briefing meeting, which allowed the coaches to they informed their athletes about our study and facilitated their participation. A space was prepared in the various hotels and training facilities, so that the athlete had enough privacy to answer the instruments in a calm and conscious way, the athlete was accompanied in this process explaining prior informed consent and the dynamics of answering the questionnaires, clarifying that their participation was completely anonymous and voluntary, therefore at the moment in which they wanted to leave the study they could do so, this dynamic helped the process of answering the questionnaires to be given in a fluid and light way for the athletes.

The statistical analyzes carried out were descriptive, mean frequencies, standard deviation and normality of data by means of kolmogórov-smirnov, reliability of Cronbach's alpha $(\propto)$ and bivariate correlations with Spearman's correlation coefficients, with the statistical package Statistical Package for the Social Sciences (SPSS) version 25.

\subsection{Results}

The sample does not meet the criteria of normality of the data, so non-parametric statistical analyzes were used for the correlations, when the variables to be contrasted do not comply with the normal distribution criterion, we will use the calculation of the Spearman correlation coefficient, from so that with this analysis the degree of association between the variables is determined, the reliability of the resistant personality was between .75 and .81 , eliminating item 12 (.40 if eliminating item 12 ), and in the total resistant personality With item 12 eliminated, it resulted in .90 (.50 without eliminating item 12), this was done through the correlation of the corrected total item Carmona-Halty, Garrosa, \& MorenoJiménez (2017) found reliability values of Alpha of Cronbach between .78 to .86 . And the reliability of the Burnout variables ranged between .40 and .82 (eliminating item 1) by means of the corrected total item correlation. Another group of researchers found the reliability of the factors between .75 to .83 (Salazar-González, Cantú-Berrueto, López-Walle, Berengüí, 2020) a study also done in athletes.

In the correlations (Tabla 1), negative and significant results were presented in the total resistant personality in the variable of physical and emotional exhaustion (PEE) with a value of $\mathrm{r}=-.209 *$ and Devaluation of Sports Practice (DSP) with a value of $r=-.265^{* *}$. In this sense, the result shows that the higher the resistant personality, the lower the PEE and the lower DSP, which presumably strengthens staying in sport voluntarily despite the fatigue that continuing to train and compete may represent. 
And the correlations of the resistant personality variables with burnout were presented in the control variable with a value $r=-.177 *$ and the commitment with a value of $r=-.281 * *$ with the devaluation of sports practice In this case, the result shows that the greater control and commitment, the greater the value the athlete perceives of the importance of his sport practice because he considers it part of his development as an athlete, and in the challenge with a value of $r=-.188 *$ with the Physical and Emotional Exhaustion (PEE) and in this same challenge variable it was correlated with the Devaluation of Sports Practice (DSP) with a value of $\mathrm{r}=-.258 * *$, with this result it is presumed that the taste for Changes, and due to new challenges, athletes consider it part of their training, so it is not relevant how physically and emotionally tired they are, it is worth continuing their preparation and this adds value to their systematic practice of training.

It is worth mentioning that there were no existing correlations with respect to the variables of resistant personality and the Reduced Sense of Achievement (RSA).

Table 5.1 Spearman's bivariate correlations of resistant personality factors and burnout

\begin{tabular}{|r|l|r|r|r|r|r|r|}
\hline \multicolumn{2}{|c|}{$\mathbf{1}$} & \multicolumn{2}{|c|}{$\mathbf{3}$} & $\mathbf{3}$ & $\mathbf{6}$ \\
\hline 1 & PR Total & & & & & \\
\hline 2 & C & $.869^{* *}$ & & & & & \\
\hline 3 & CO & $.564^{* *}$ & $.467^{* *}$ & & & & \\
\hline 4 & CH & $.850^{* *}$ & $.621^{* *}$ & $.470^{* *}$ & & & \\
\hline 5 & RSA & -0.049 & -0.078 & -0.053 & -0.040 & & \\
\hline 6 & PEE & $-.209^{*}$ & -0.161 & -0.118 & $-.188^{*}$ & $.696^{* *}$ & $.677^{* *}$ \\
\hline 7 & DSP & $-.265^{* *}$ & $-.177^{*}$ & $-.281^{* *}$ & $-.258^{* *}$ & $.732^{* *}$ \\
\hline
\end{tabular}

Note: C (Control); CO (Commitment); CH (Challenge); RSA (Reduced Sense of Achievement); PEE (Physical and Emotional Exhaustion); DSP (Devaluation of Sports Practice); * $\mathrm{p}<.05 ; * * \mathrm{p}<.01$

\subsection{Acknowledgements}

Our gratitude to the Facultad de Organización Deportiva, Universidad Autónoma de Nuevo León, CONACYT, and REDDECA, which continues to support this type of research to the best of its ability. Also, our thanks to the athletes, coaches and organizing committee.

\subsection{Conclusions}

The PR factors that correlate with the Burnout variables are commitment, control and challenge (trifactorial), therefore, it was tested whether there is also a unifactorial relationship of the total resistant personality and the existing relationship is effectively confirmed. in the variable of physical emotional exhaustion and the devaluation of sports practice. Confirming the answer to the hypothesis raised.

Therefore, the conclusions of the present investigation are the following:

A resistant personality implies a high resistance to stress, which predisposes athletes to perceive problems with greater lightness and ability to solve difficulties and at the same time feel capable of solving whatever it is during competitions, and in this research athletes show a low burnout and a high resistant personality, they do not feel exhausted, physically or mentally, and they value their sports practice. Their love of their sport has kept them motivated over the years.

Emotional control in various situations ensures sporting success, since it maintains the balance and order of the athletes' mental processes and being involved in an activity that they enjoy does not allow negative feelings or loss of interest in their sport.

High performance athletes are highly committed people, they go about specific objectives, focused on a task, in search of achievable goals in the short to medium and long term, these characteristics have led them to achieve the highest objectives that have been set, they are athletes who prefer to make an effort every day in training in order to perceive themselves as successful, aware that this takes a process that can take years. 
Challenges are part of the growth and development processes of high-performance athletes, they learn to achieve goals and establish new and greater new challenges each season, they are excited by the permanent idea of improving and involving themselves in body and spirit during their training, the challenges are opportunities to achieve new records, new brands, new experiences that they consider positive for their training. therefore, the practice of judo for these athletes has become a very incredible way of life, learning and experiences that make them feel successful.

The judokas in this sample are perceived to be successful, warriors, successful, able to resist any degree of stress, they love their sport and want to stay in it for many years, which is a mental, emotional and physical benefit.

\subsection{References}

Ato, M., López-García, J. J., y Benavente, A. (2013). Un sistema de clasificación de los diseños de investigación en psicología. Anales de Psicología/Annals of Psychology, 29(3), 1038-1059.

Avilés, I. E., Morey, G. J., Rivera, C. L., \& Chévere-Rivera, K. (2018). Sobre-Entrenamiento: Relación entre el Estrés y la Recuperación en Atletas Jóvenes en Deportes de Combate-Revista de Entrenamiento Deportivo. Revista de Entrenamiento Deportivo, 32(3).

Balaguer, I., Castillo, I., Duda, J. L., Quested, E., y Morales, V. (2011). Predictores sociocontextuales y motivacionales de la intención de continuar participando: Un análisis desde la SDT en danza. Revista Internacional de Ciencias del Deporte, 25(7), 305-319. doi: 10.5232/ricyde2011.02505.

Bauman, A., Bellew, B., y Craig, C. L. (2014). Did the 2000 Sydney Olympics increase physical activity among adult Australians? British Journal of Sports Medicine, 49(4), 7-243. http://dx.doi.org/10.1136/bjsports-2013-093149

Bronfenbrenner, U. (1979). Contexts of child rearing: Problems and prospects. American Psychologist, 34(10), 844-850. http://dx.doi.org/10.1037/0003-066X.34.10.844

Carmona-Halty, M., Garrosa, E., \& Moreno-Jiménez, B. (2017). Análisis psicométrico de la Escala de Personalidad Resistente (EPR) adaptada a estudiantes universitarios chilenos. Interciencia, 42(5), 286292.

De la Cruz Alvarado, A. J. (2020). La motivación en la autoconfianza de deportistas universitarios; una revisión de la literatura científica en los últimos diez años (Tesis de licenciatura). Recuperada de https://repositorio.upn.edu.pe/bitstream/handle/11537/26377/Trabajo\%20de\%20investigaci\%C3\%B3n. pdf? sequence $=1$ \&isAllowed $=\mathrm{y}$

Figueroa Solórzano, M. A., \& Patiño Bautista, K. V. (2021). Asociación entre síndrome de Burnout y la frecuencia de lesiones deportivas en futbolistas de divisiones inferiores de clubes profesionales del Perú (Tesis de licenciatura). Recuperada de https://repositorio.cientifica.edu.pe/handle/20.500.12805/1760

Gonzales Salazar, M. C. (2021). Síndrome de Burnout y Autoeficacia general en personales de salud en el ámbito deportivo. (Tesis de licenciatura). Recuperado https://repositorioacademico.upc.edu.pe/bitstream/handle/10757/655731/GonzalesS_M.pdf?sequence= 3

Ponce, N. (2017). Contexto social, personalidad resistente y dureza mental en deportistas centroamericanos y del caribe (Tesis doctoral). Recuperado de http://eprints.uanl.mx/12821/

Ponce-Carbajal, N., López-Walle, J. M., Jaenes, J. C., Medina, M., \& Cocca, A. (2015). Análisis factorial confirmatorio de segundo orden del Cuestionario de Personalidad Resistente en deportistas centroamericanos. [Resumen]. XXIII Memorias del Congreso Mexicano de Psicología, Alcances de la Psicología en las Políticas Nacionales. Cancún, México. 
Jaenes, J. C., Godoy, D., \& Román, F. M. (2009). Personalidad resistente en maratonianos: un estudio sobre el control, compromiso y desafío de corredoras y corredores de maratón. Revista de Psicología del Deporte, 18(2), 217-234.

Jaenes, J. C., Godoy, D., \& Román, F. (2008). Elaboración y validación psicométrica de la Escala de Personalidad Resistente en Maratonianos. Cuadernos de Psicología del Deporte, 8(2), 59-81.

Kobasa, S. (1979). Stressful live events personality and health an inquiry in to hardiness. Journal of Personality and Social Psychology, 37(1), 1-11.http://dx.doi.org/10.1037/0022-3514.37.1.1

Raedeke, T. D., y Smith, A. L. (2001). Development and preliminary validation of a measure of athlete burnout. Journal of Sport \& Exercise Psychology, 23, 281-306. Doi: 10.1123/jsep.23.4.281

Salazar-González, D., Cantú-Berrueto, A., López-Walle, J.M., Berengüí, R. (2020). Cuestionario de Burnout Deportivo (ABQ): análisis y validación en el deporte mexicano. Cuadernos de Psicología del Deporte, 20(2), 189-200. 